\title{
PENGEMBANGAN SMU BERKUALITAS (PLUS) \\ DARI ASPEK PENGEMBANGAN SISWA DAN GURU
}

\author{
Suto Prabowo
}

\begin{abstract}
Abstrak
Dewasa ini Arus Komunikasi dan Informasi melaju dengan cepat mengakibatkan timbulnya persaingan di segala bidang kehidupan diantara bangsa-bangsa. Keadaan demikian menuntut adanya sumber daya manusia yang berkualitas yang memiliki: bakat, kemampuan dan kecerdasan luar biasa. Upaya untuk menjawab tantangan dan tuntutan demikian perlu dikembangkan pendidikan sekolah yang berkualitas, antara lain Sekolah Menengah Plus. Sekolah Menengah Plus adalah SMU yang dipersiapkan untuk dapat dikembangkan menjadi SMU yang memiliki ciri-ciri plus. Dengan mengembangkan SMU Plus berarti juga menjawab permasalahan Pendidikan di Indonesia yang meliputi: 1). Pemerataan pendidikan dalam Pembangunan Indonesia; 2) Relevansi pendidikan dengan Pembangunan Indonesia; 3) Peningkatan Mutu Pendidikan di Indonesia; 4) Peningkatan Efisiensi dan Efektivitas Pendidikan di Indonesia
\end{abstract}

Kata Kunci: Pengembangan, SMU Berkualitas (Plus), Aspek Pengembangan Siswa dan Guru.

Pendidikan di Era Globalisasi terus berkembang seiring dengan percepatan perkembangan ilmu teknologi dan informasi. Dengan arus komunikasi dan informasi yang melaju cukup deras, maka terbukalah persaingan bebas di antara bangsabangsa di segala bidang. MKeadaan demikian menuntut adanya sumber daya manusia yang berkualitas. Namun perlu disadari, untuk maksud demikian tidaklah mudah, apalagi kondisi sumber daya manusia kita masih memprihatinkan. Oleh karena itu Departemen Pendidikan kita berupaya menciptakan kondisi bagi terbentuknya manusia berkualitas.

Sumber daya manusia berkualitas adalah sumber daya manusia yang memiliki kualitas dalam ketahanan fisik dan mental, penguasaan ilmu dan teknologi, jujur, disiplin, bertanggung jawab, dedikasi, setia terhadap nusa dan bangsa, berorientasi ke masa depan serta beriman dan bertaqwa terhadap Tuhan Yang Maha Esa.

Di sisi lain, Sistem Pendidikan Nasional telah tanggap akan perlunya wadah dan bentuk sekolah berkualitas, hal itu dituangkan dalam UU No.2/1989, pasal 8 ayat 2 berbunyi demikian "Warga negara yang memiliki kemampuan dan jsh Jurnal Sosial Humaniora, Vol 7 No.2, November 2014 
kecerdasan luar biasa berhak memperoleh perhatian khusus". Dengan demikian pemerintah bertanggung jawab memberikan wadah dan tempat bagi peserta didik yang memiliki kemampuan dan kecerdasan luar biasa. Virget S. Ward menjelaskan bahwa pendidikan bagi anak-anak yang berbakat perlu perhatian yang seksama. Dia mengajukan argumentasi sebagai berikut:

a. Persepsi demokrasi menghendaki pemberian kesempatan yang luas bagi anak dan pemuda berbakat dengan potensinya yang melebihi anak-anak normal agar dia dapat berkembang lebih baik.

b. Keberhasilan pendidikan bagi anak-anak dan pemuda yang berbakat memberi peluang yang lebih besar kepada mereka untuk memberikan dukungan dan sumbangan kepada masyarakat.

c. Selama ini sistem pendidikan kita (terutama di sekolah-sekolah) kurang memperhatikan pendidikan bagi anak-anak yang berbakat ini (Hamalik, 2000).

Salah satu upaya untuk menjawab tantangan dan tuntutan di atas maka penulis berpendapat perlu dikembangkan sekolah berkualitas.

1. Landasan

Dalam UU No.2/1989 tentang Sistem Pendidikan Nasional terdapat pasal-pasal yang menunjang penyelenggaraan "Sekolah Menengah Plus" seperti tersebut di bawah ini:

- Pasal 8 ayat 2: Warga negara yang memiliki kemampuan dan kecerdasan luar biasa berhak memperoleh perhatian khusus.

- Pasal 24 ayat 2 : Mendapatkan perlakuan sesuai dengan bakat, minat dan kemampuannya.

- Pasal 24 ayat 6 : Setiap peserta didik berhak menyelesaikan program pendidikan lebih awal dari waktu yang telah ditentukan.

- Pasal 26 : Peserta didik berkesempatan untuk mengembangkan kemampuan dirinya dengan belajar setiap saat dalam perjalanan hidupnya sesuai dengan bakat dan kemampuannya masing-masing. 
Berdasarkan kutipan perundang-undangan sebagaimana tersebut di atas, maka dapat penulis simpulkan bahwa penyelenggaraan sekolah plus memiliki dasar hukum yang kuat dan dapat dipertanggung jawabkan.

\section{PENGEMBANGAN SMU PLUS}

Pengertian

Yang dimaksud dengan Sekolah Menengah Plus adalah SMU yang dipersiapkan untuk dapat dikembangkan menjadi SMU yang memiliki ciri-ciri plus yaitu :

1. Memiliki sejumlah siswa yang dengan bakat-bakat khusus dengan kemampuan dan kecerdasan yang tinggi.

2. Memiliki tenaga guru profesional yang handal.

3. Melaksanakan kurikulum yang diperkaya.

4. Memiliki sarana dan prasarana yang memadai.

5. Memiliki sumber dana mandiri.

Konsep SMU Plus sejalan dengan konsep tentang sekolah unggul, Good School, Success School, Excellence School atau High Performance School (Arifin, 1998). Imron Arifin mengemukakan ada 10 karakteristik Sekolah Unggulan yaitu :

1. Fasilitas belajar yang baik.

2. Layanan akademik yang baik.

3. Perencanaan yang baik.

4. Iklim kerja dan belajar yang sehat dan baik.

5. Motivasi berprestasi dan semangat kerja yang tinggi.

6. Menerapkan sistem guru vak/mata pelajaran secara konsekuen.

7. Kemampuan dasar murid yang baik.

8. Harapan yang tinggi disertai dukungan orang tua dan masyarakat.

9. Keterlibatan secara aktif dari para staf dan guru.

10. Kepala Sekolah yang efektif (Arifin, 1998, dikembangkan). 


\section{MISI DAN TUJUAN}

Adapun yang menjadi misi dan tujuan dikembangkannya Sekolah Menengah Unggulan (SMU Plus) adalah :

1. Menghimpun peserta didik yang memiliki bakat khusus, kemampuan dan kecerdasan tinggi dari berbagai wilayah untuk dapat dikembangkan secara optimal. Diharapkan setiap wilayah memiliki warga yang mempunyai kecerdasan dan kemampuan yang luar biasa, yang dapat membangun daerah pada masa yang akan datang.

2. SMU Unggulan diproyeksikan untuk dapat dijadikan pusat keunggulan (Agent of Excellence), sehingga dapat menciptakan persaingan yang sehat dan motivasi bagi SMU lain di wilayahnya.

3. Keberhasilan dalam setiap lomba kegiatan karya ilmiah remaja pada tingkat regional dan intenasional, sehingga siswa terbiasa dan terlatih dalam penelitian serta terhimpunnya siswa berbakat khusus.

4. Memiliki keterampilan berbahasa Inggris, mengingat lokasi waktu pelajaran bahasa Inggris di SMU terbatas, maka perlu diusahakan membentuk kelompok-kelompok siswa yang setiap hari berbahasa Inggris, khususnya melalui kegiatan ekstra kurikuler.

5. Sekolah mampu menciptakan $6 \mathrm{~K}$ (ketertiban, keamanan, kebersihan, keindahan, kekeluargaan dan kerindangan).

Pengembangan SMU Plus ini juga untuk menjawab masalah pendidikan di Indonesia yang meliputi :

1. Pemerataan pendidikan dalam pembangunan.

2. Relevansi pendidikan dengan pembangunan.

3. Peningkatan mutu pendidikan.

4. Peningkatan effisiensi dan efektivitas pendidikan. 


\section{PERENCANAAN PENGEMBANGAN SISWA DAN GURU}

1. Spesifikasi Tujuan

Yang menjadi misi/tujuan perencanaan ini adalah menghasilkan siswa yang berpotensi dan guru yang memiliki komitmen yang tinggi terhadap pendidikan.

Spesifikasi tujuan bagi siswa SMU Plus diharapkan dapat menciptakan manusiamanusia berpotensi yang memiliki ciri-ciri :

a. Dedikasi dan disiplin

b. Jujur

c. Inovatif

d. Tekun

e. Ulet (Tilaar, 1999)

Keberhasilan siswa dinyatakan melalui indikator yang menunjukkan hasil sebagai berikut:

a. Kelulusan SMU Plus memiliki rata-rata NEM 7,00 atau lebih untuk setiap program (jurusan), sebagai akibat pembinaan yang profesional.

b. Memiliki tingkat keberhasilan yang tinggi untuk masuk ke Perguruan Tinggi ternama (Ditdikmenum, 1996).

Sedang spesifikasi tujuan bagi guru adalah profesionalisme guru. Guru profesional adalah guru yang melaksanakan tugas keguruan dengan kemampuan tinggi. Dalam menjalankan kewenangan profesionalnya, guru dituntut memiliki keanekaragaman kecakapan atau kompetensi yang meliputi:

a. Kompetensi kognitif

b. Kompetensi afektif

c. Kompetensi psikomotor (Muhibbin Syah, 1995)

2. Analisa Performan Siswa dan Guru

a. Standart Performan Siswa, sebagai berikut:

Siswa diharapkan memiliki:

1. Keimanan dan ketaqwaan terhadap Tuhan Yang Maha Esa.

2. Nasionalisme dan Patriotisme yang tinggi. 
3. Berkepribadian Pancasila.

4. Wawasan Iptek yang luas dan mendalam.

5. Motivasi dan komitmen yang tinggi untuk berprestasi.

6. Kepekaan sosial dan kepemimpinan.

7. Disiplin yang tinggi.

8. Kondisi fisik yang prima.

9. Gemar membaca dan meneliti.

10. Kemampuan berbahasa yang baik dan benar.

11. Kemampuan bernahasa Inggris yang baik dan lancar (Ditdikmenum, 1996).

b. Standart Performan untuk Guru, sebagai berikut:

HAR Tilaar mengemukakan performan guru profesional sebagai berikut:

1. Kepribadian yang matang dan berkembang.

2. Penguasaan ilmu pengetahuan dan teknologi yang kuat.

3. Keterampilan membangkitkan minat peserta didik.

4. Pengembangan profesi yang berkesinambungan (Tilaar, 1999) Menurut Wijaya (1991) standard performan kepribadian guru sebagai berikut:

1. Memiliki kepribadian yang mantap.

2. Memiliki kepekaan terhadap perubahan dan pembaharuan.

3. Memiliki kemampuan berfikir alternatif.

4. Berlaku adil, jujur, obyektif, bijaksana, sederhana.

Selanjutnya Wijaya mengemukakan standart performan untuk kemampuan profesional guru sebagai berikut:

1. Menguasai bahan meliputi bahan bidang studi, isi buku teks dan kurikulum.

2. Menguasai bahan pendalaman, yang diwujudkan dalam mempelajari ilmu yang relevan, mempelajari aplikasi bidang ilmu ke dalam ilmu lain.

3. Mampu merumuskan tujuan pembelajaran yang berwujud ciri-ciri TPU dan TPK.

4. Dapat mengenal dan menggunakan metode mengajar dengan bentuk mempelajari macam-macam metode dan penggunaannya. 
5. Mampu mengelola interaksi belajar mengajar, dengan mempelajari cara-cara memotivasi dan menggunakannya, mempelajari bentuk pelayanan dengan menggunakannya.

Untuk menilai performance-performance di atas menggunakan beberapa cara:

1. Untuk menilai pengetahuan dapat dilakukan melalui angket atau daftar pertanyaan.

2. Untuk menilai kemampuan pribadi dan komitmen, dilakukan melalui pengamatan dan observasi.

3. Untuk menilai kemampuan, dapat dilakukan dengan menggunakan berbagai bentuk test sesuai spesifikasi masing-masing.

3. Analisa Alat dan Metode

1. Analisa alat dan metoda bagi siswa:

Alat dan metoda untuk meningkatkan kualitas siswa menggunakan metoda sebagai berikut:

a. Seleksi siswa dengan jalan:

- $\quad$ Psikotes untuk mengetahui tingkat kecerdasan dan kepribadian siswa.

- Prestasi belajar di SLTP (NEM dan Raport).

- $\quad$ Rekomendasi dari Kepala SLTP.

- Kesehatan.

- Latar belakang kehidupan siswa (hobbi, prestasi di luar sekolah, kegiatan kemasyarakatan).

b. Kegunaan belajar siswa

Kegiatan ini dikelompokkan menjadi 3 bagian yaitu:

1. Kegiatan proses pembelajaran di kelas, yang meliputi kegiatan intra kurikuler dan kokurikuler, kedua kegiatan ini lebih dipusatkan pada aktivitas siswa, guru berperan sebagai fasilitator dan mediator.

2. Kegiatan ekstra kurikuler untuk menyalurkan bakat dan kemampuan siswa dalam: olah raga, kesenian, keagamaan, karya ilmiah, seminar dan pramuka.

3. Kegiatan bimbingan karir yang meliputi: informasi melanjutkan ke Perguruan Tinggi, informasi penjurusan, informasi terjun ke dunia kerja, informasi kegiatan ekstra kurikuler. 
c. Evaluasi siswa

1. Macam-macam evaluasi siswa

- Evaluasi hasil belajar siswa, baik berupa kognitif, afektif dan psikomotor.

- Evaluasi kepribadian, yang termasuk aspek kepribadian adalah disiplin, toleransi, akhlak, kerjasama, kreativitas, kepemimpinan dan tanggung jawab.

- Evaluasi keimanan dan ketaqwaan.

2. Analisa Alat dan Metode bagi Guru.

Untuk pengembangan atau peningkatan kualitas guru digunakan alat dan metode sebagai berikut:
A. Pengadaan Guru melalui Seleksi

Proses seleksi guru didasarkan pada manajemen sumber daya manusia yang menitik beratkan apakah sekelompok guru telah memenuhi tuntutan lembaga/organisasi.

Adapun langkah yang bisa ditempuh dalam proses seleksi ialah:

a. Penerimaan surat lamara.

b. Penyelenggaraan ujian.

c. Wawancara seleksi.

d. Pengecekan latar belakang pelamar dan surat-surat referensinya.

e. Evaluasi kesehatan.

f. Wawancara oleh manager yang akan menjadi atasan langsung.

g. Pengenalan pekerjaan.

h. Keputusan atas lamaran (Siagian, 1993).

Bagi SMU Plus yang pada tahun pertama belum memenuhi persyaratan ketenagaan terutama tenaga edukatif perlu dikembangkan kemampuan ketenagaan, sehingga pada tahun-tahun selanjutnya dapat melaksanakan kegiatan proses pembelajaran sebagaimana yang dipersyaratkan. Pengadaan dan pembinaan ketenagaan dilakukan dengan memperhatikan salah satu atau beberapa strategi berikut:

a. Mengusulkan tenaga baru. 
b. Menyesuaikan kemampuan tenaga yang telah ada dan dipandang memenuhi kualifikasi akademiknya agar mampu menyelenggarakan kegiatan proses pembelajaran sebagaimana yang telah dipersyaratkan.

c. Menugas belajarkan tenaga kependidikan yang ada khusus kepada mereka yang belum memenuhi persyaratan.

d. Merekrut tenaga luar biasa dari lembaga pendidikan tertier yang ada di wilayah sekitar.

\section{B. Pengembangan Karir}

Pengembangan karir dalam hal ini identik dengan strategi pembinaan ketenagaan. Pada awal kegiatan ini dilakukan penelusuran kemampuan profesional guru dan tenaga kependidikan lainnya. Dalam upaya penelusuran kemampuan profesional tersebut dilakukan dalam dua bentuk yaitu:

a. Program yang diperuntukkan bagi para guru dan kependidikan lainnya yang baru diangkat.

b. Penelusuran yang secara khusus dipersiapkan bagi mereka yang berstatus dimutasikan dari sekolah atau tempat tugas lain.

Bagi mereka yang baru diangkat sebagai guru atau tenaga kependidikan lainnya akan diberikan test kemampuan akademik dan bentuk test lain yang diperlukan untuk menilai kemampuan awal yang mereka miliki. Selanjutnya data tersebut akan dijadikan dasar dalam memberikan program pelatihan yang lebih sesuai dengan kebutuhan sekolah.

Adapun mereka yang sudah berstatus pegawai negeri akan diberikan program pelatihan dengan memperhatikan:

a. Jenjang pendidikan

Dalam menjaring data mengenai latar belakang pendidikan persekolahan yang telah ditempuh oleh tenaga kependidikan SMU Plus (guru dan non guru) dapat di klasifikasikan:

1. Mereka yang berlatar belakang pendidikan yang sesuai dengan jenis mata pelajaran yang diajarkan atau jenis tugas yang diemban dalam penyelenggaraan Sekolah Plus. 
2. Mereka yang berlatar belakang pendidikan yang tidak sesuai dengan jenis tugas yang diemban di SMU Plus tersebut.

b. Pengalaman Profesional

Dalam menjaring data mengenai latar belakang pengalaman profesional tenaga kependidikan yang ada dapat dibedakan menjadi:

1. Yang sesuai dengan bidang keahliannya.

2. Yang tidak sesuai dengan kewenangan utama dalam bidang tersebut.

\section{PENUTUP}

Implementasi dari perencanaan ini dilakukan secara bertahap dan periodik. Seleksi calon siswa dilaksanakan pada awal tahun pelajaran baru, kemudian selalu dievaluasi perkembangan siswa selama kegiatan belajar mengajar berlangsung baik kegiatan pembelajaran di kelas, ekstra kurikuler maupun keaktifan berkonsultasi tentang rencana studi. Disamping itu seleksi calon guru juga selalu dilakukan setiap waktu sesuai dengan kebutuhan sekolah, dan juga selalu diupayakan dan dilaksanakan pengembangan karir dan profesional guru dengan berbagai cara yang positif dan praktis.

Penilaian dan monitoring secara cermat dilakukan terus menerus sehingga jika terjadi penyimpangan dari pelaksanaan ini dapat segera diantisipasi dengan segera dan berulang-ulang sampai pada hasil yang optimal. 


\section{DAFTAR PUSTAKA}

Amiruddin, A, Aspirasi Peningkatan Kemampuan Profesional dan Kesejahteraan Guru. Jakarta, 2000

Arifin, Imron, Kepemimpinan Kepala Sekolah Dalam Mengelola Madrasah Ibidaiyah dan Sekolah Dasar Berprestasi : Studi Multi Kasus MIN, Malang I, MI Mamba'ul Ulum dan SDN Ngaglik I Batu di Malang. Disertai, PPS IKIP Malang, Malang, 1998.

Ditdikmenum, Petunjuk Teknis Pengelolaan SMU Plus. Ditjendikdasmen, Jakarta, 1996.

Hamalik, Oemar, Psikologi Belajar dan Mengajar. Sinar Baru Algensindo, Bandung, 2000.

Pidarta, Made, Landasan Kependidikan Stimulus Ilmu Pendidikan Bercorak Indonesia. Rineka Cipta, Jakarta, 1990.

Pidarta, Made, Perencanaan Pendidikan Partisipatori Dengan Pendekatan Sistem. Rineksa Cipta, Jakarta, 1990.

Siagian, Sondang P, Manajemen Sumber Daya Manusia. Bumi Aksara, Jakarta, 1993.

Sukardi, Dewa K, Bimbingan Karir di Sekolah-sekolah. Ghalia Indonesia, Jakarta, 1985.

Syah, Muhibbin, Psikologi Pendidikan dengan Pendekatan Baru. PT. Remaja Rosdakarya, Bandung, 2000.

Tilaar, H.A.R, Beberapa Agenda Reformasi Pendidikan Nasional. Indonesia Terang, Magelang, 1999. 